\title{
Kebijakan redaksi media di Indonesia dalam pemberitaan haji tahun 2020
}

\author{
Ida Nuraini Dewi Kodrat Ningsih ${ }^{1^{\star}}$, Narayana Mahendra Prastya ${ }^{2}$ \\ 1,2 Universitas Islam Indonesia
}

\begin{abstract}
There was uncertainty in Hajj 2020 due to the Covid-19 pandemic. Before the Kingdom of Saudi Arabia's government announced the limitation of Hajj 2020, several countries including Indonesia has decided not to cancel the hajj trip. In dealing with uncertain information, the public needs valid information because uncertainty leads to speculations. In this situation, the media has a vital role in giving valid and verified information. This article aims to know how Indonesia media editorial policy in hajj 2020 news coverage. The editorial policy consists of the news theme, news sources, and news reporting technique. The data collection use interview with five informants from different media. The results before the official announcement, media deliver the news about the future of Hajj 2020 and the Indonesian government plan in dealing with the situation. After the official announcement both from Indonesia and Saudi Arabia gov't, the media deliver information about the procedure to refund the hajj fee. News sources are the Ministry of Religion of the Republic of Indonesia, pilgrims, and travel agencies, and umrah. News reporting techniques use teleconference, citing information from authority's official websites, and citing news from other news agencies.

Keyword : crisis situations, editorial policy, Hajj 2020 news coverage

Abstrak: Pelaksanaan ibadah haji tahun 2020 sempat dilanda ketidakpastian akibat penularan Covid-19 yang belum terkendali. Sebelum pemerintah Kerajaan Saudi Arabia mengumumkan pembatasan dalam pelaksanaan haji, sejumlah negara termasuk Indonesia telah memutuskan untuk tidak memberangkatkan jamaah haji. Menghadapi situasi yang tidak pasti, masyarakat memerlukan informasi yang valid karena ada banyak spekulasi dan pendapat yang bermunculan. Disinilah media memiliki peranan penting dalam memberikan informasi yang jelas bagi masyarakat. Tulisan ini bertujuan untuk mengetahui kebijakan redaksional media massa di Indonesia dalam memberitakan haji tahun 2020. Kebijakan redaksional mencakup pemilihan tema berita, narasumber dan teknik liputan. Pengambilan data menggunakan teknik wawancara terhadap lima media di Indonesia. Hasil penelitian, secara umum sebelum adanya pengumuman resmi dari otoritas baik Indonesia maupun Saudi Arabia, media menyajikan berita dengan tema kepastian pelaksanaan haji dan langkah-langkah antisipasi pemerintah Indonesia. Setelah adanya pengumuman resmi, tema berita adalah prosedur pengembalian uang jamaah. Media menggunakan sumber berita yakni Kementerian Agama RI, jamaah haji, dan travel biro dan umrah. Ada pun teknik liputan selama pandemik dilakukan dengan cara wawancara jarak jauh (telekonferensi), menggunakan informasi yang ada di laman resmi otoritas haji, dan mengutip dari pemberitaan media atau kantor berita lain.
\end{abstract}

Kata Kunci: kebijakan redaksi, pemberitaan haji 2020, situasi krisis

"Corresponding Author: Ida Nuraini Dewi Kodrat Ningsih | ida.nuraini@uii.ac.id | Fakultas Psikologi dan IImu Sosial Budaya, Universitas Islam Indonesia, JI. Kaliurang No.Km. 14,5, Krawitan, Sleman, Daerah Istimewa Yogyakarta, Indonesia 


\section{Pendahuluan}

Penanganan kesehatan merupakan hal yang paling penting guna mengantisipasi penyebaran Covid-19. Namun begitu, Covid-19 juga memiliki dampak turunan yang tidak kalah besarnya. Seperti dikutip dari majalah Etika (Dewan Pers, 2020) bahwa : "yang dibutuhkan saat ini tidak sebatas pada penanganan medis terhadap masyarakat yang terpapar atau diduga terpapar virus corona, tetapi juga dampak turunan pandemi Covid-19".

Salah satu dampak turunan Covid-19 adalah pelaksanaan ibadah, termasuk juga ibadah haji di tahun 2020. Pemerintah Kerajaan Arab Saudi pada tanggal 22 Juni 2020 (waktu setempat) mengumumkan secara resmi bahwa ibadah haji tetap diselenggarakan dengan pemabatasan secara ketat - mulai dari jumlah jamaah, usia, kondisi kesehatan, dan jamaah hanya khusus mereka yang sudah berada di Arab Saudi dalam kurun waktu tertentu (Mabruroh, 2020).

Sebelum Arab Saudi mengeluarkan pengumuman resmi berkaitan dengan haji tahun 2020, sejumlah negara termasuk Indonesia memutuskan batal memberangkatkan jamaah haji karena kondisi penularan Covid-19 yang tidak terkendali. Pemerintah Republik Indonesia (RI) melalui Kementerian Agama Republik Indonesia (Kemenag RI) pada tanggal 2 Juni 2020 mengeluarkan Keputusan Menteri Agama Republik Indonesia Nomor 494 Tahun 2020 tentang Pembatalan Keberangkatan Jemaah Haji pada Penyelenggaraan Ibadah Haji Tahun $1441 \mathrm{H} / 2020 \mathrm{M}$.
Tulisan ini betujuan untuk mengetahui bagaimana kebijakan redaksional media massa di Indonesia dalam pemberitaan mengenai haji tahun 2020. Secara singkat, kebijakan redaksional adalah panduan bagi sebuah media untuk menentukan pemberitaan dengan mengatur mengenai apa saja isu yang diangkat, apa saja sumber berita yang digunakan, dan cara penyajian berita (Abrar, 2019; Eriyanto, 2002; Gonzales, 2017; Kedoh, 2018).

Dua alasan peneliti memilih membahas kebijakan redaksional dalam tulisan ini adalah: pertama, keputusan pemerintah Indonesia tidak memberangkatkan haji tahun 2020 dapat memicu perdebatan di masyarakat, dan ditambah lagi adanya sejumlah berita bohong seperti penyelewengan penggunaan dana haji sampai dengan kabar tentang Aceh yang akan memberangkatkan jamaah haji sendiri (Yuniar, 2020). Sejumlah perdebatan yang bermunculan setelah keputusan pemerintah RI tentang haji tahun 2020 membuat situasi ini berpotensi menjadi krisis (Prastya \& Utami, 2020). Media memiliki peran vital dalam situasi krisis sehingga diibaratkan sebagai dokter dan perawat yang menyuplai kebutuhan harian akan asupan informasi serta menyembuhkan kesesatan informasi yang terjadi ketika krisis. Untuk kasus Covid-19, maraknya misinformasi dan/atau disinformasi menjadi problem tersendiri, selain bahaya dari virus tersebut (Mongglio, 2020).

Alasan kedua adalah haji selama ini menjadi merupakan peristiwa yang memiliki nilai berita yang tinggi. Bahkan, 
masifnya pemberitaan seputar haji di media massa dipandang sebagai upaya dari media tersebut untuk meraih keuntungan dan peristiwa haji diperlakukan sebagai komoditas semata. Pemberitaan haji secara besar-besaran memberikan media peluang untuk meningkatkan jumlah pembaca. Pertambahan jumlah pembaca membuat jumlah iklan yang masuk akan semakin banyak (Hadi, 2015). Bahkan, ada kalanya media menyajikan hal-hal yang kurang substantif seperti memberitakan apa busana yang dikenakan oleh jamaah ketika kembali ke kampung halamannya, dibandingkan mengedepankan berita yang mengedepankan sensibilitas pelayanan haji (Kasman, 2019). Adanya perubahan situasi pada haji 2020 akan turut mengubah bagaimana kebijakan redaksional media dalam memberitakan pelaksanaan rukun Islam ke-lima tersebut.

\section{Tinjauan pustaka}

Media massa memerlukan kebijakan redaksional dalam menyajikan pemberitaan, sebagai panduan bagi wartawan dan media untuk menentukan topik yang diangkat dan siapa narasumber yang diwawancarai (Eriyanto, 2002). Pengertian lain kebijakan redaksional, menurut Gonzales (2017) menyatakan bahwa kebijakan redaksional merupakan orientasi konsisten yang ditunjukkan oleh sebuah media dengan cara menyeleksi isu atau peristiwa dan cara mempublikasikannya. Ada pun Abrar (2019) dan Kedoh (2018) menyatakan kebijakan redaksional merupakan kaidah bagi operasional pemberitaan di sebuah media pers yang menjadi pedoman redaksi media dalam menentukan isu liputan, sudut pandang liputan, isi berita, nilai berita, memilih narasumber, penugasan, format berita, penyuntingan berita, penyajian berita termasuk juga pengelompokan berita berdasarkan rubrik atau program tertentu. Kebijakan redaksional merupakan gabungan antara kebutuhan khalayak media pers dan cita-cita institusional media pers. Tanpa adanya kebijakan redaksional maka pemberitaan media dipastikan tidak akan konsisten.

Media memiliki peranan penting karena ketidakpastian yang muncul saat situasi bencana membuat kebutuhan masyarakat akan berita bencana meningkat tajam. masyarakat selalu ingin tahu dan memerlukan informasi tentang berbagai hal seputar bencana, penyebab, korban, kerugian, dampak secara luas, penanggulangan, dan hal-hal terkait lainnya. Media massa akan menjadi sumber informasi yang pertama, yang paling penting, bahkan satu-satunya informasi yang akan membentuk pengetahuan masyarakat mengenai bencana (Nazaruddin, 2007). Undangundang Republik Indonesia Nomor 24 Tahun 2007 tentang Penanganan Bencana menyebutkan bahwa wabah penyakit merupakan bentuk bencana non alam (Pasal 1 ayat).

Selain bencana alam, wabah penyakit juga merupakan salah satu bentuk dari krisis dalam kategori unintentional, krisis yang terjadi di luar campur tangan manusia dan bahkan tidak terelakkan untuk terjadi. Situasi krisis menuntut peran media untuk memberikan informasi kepada masyarakat tentang apa yang terjadi, siapa yang harus bertanggungjawab terhadap krisis, apa dampak krisis terhadap masyarakat, dan apa yang harus masyarakat lakukan (Puspitasari, 2016). 
Untuk situasi Covid-19, selain memberitakan dan mengulas hal-hal berkaitan dengan klinis mau pun sistem layanan kesehatan, media dan jurnalis juga perlu untuk menyajikan informasi dan membahas pada hal-hal yang merupakan dampak turunan dari Covid19 (Parahita, 2020).

Peran media massa dalam situasi krisis tidak berkurang meski saat ini masyarakat dapat mengakses informasi dari internet (Wibhisono, 2020). Studi yang dilakukan oleh Rochyadi-Reetz dkk (2020) terhadap penggunaan media di Indonesia semasa pandemi Covid-19 menunjukkan $45 \%$ responden mengaku menjadi lebih sering dalam menggunakan media massa dibanding sebelumnya. Media massa (berita/produk jurnalistik) cenderung digunakan oleh responden yang memiliki tingkat pendidikan tinggi.

Dalam situasi normal, media massa memang tidak menjadi referensi utama dalam pencarian informasi seputar haji. Penelitian Caidi (2019) menunjukkan bahwa tiga sumber yang paling banyak digunakan guna mencari informasi seputar ersiapan keberangkatan haji adalah Al Qur'an, buku, dan website seputar tentang panduan perjalanan haji. Kondisinya berbeda dalam kejadian luar biasa, media massa menjadi rujukan masyarakat guna mencari informasi. Penelitian terhadap calon jamaah haji asal Australia menunjukkan bahwa $78 \%$ responden mengatakan menggunakan media massa sebagai sumber informasi mengenai wabah virus Ebola yang sempat membayangi pelaksanaan haji tahun 2014-2015. Media massa atau kantor berita seperti CNN atau Reuters banyak membagikan informasi tentang virus Ebola melalui akun resmi media sosial dari kantor berita tersebut (Alqahtani et al., 2015).

Meski begitu, di sisi lain media juga dapat membuat situasi krisis menjadi semakin lebih buruk karena pemberitaan media dapat mempengaruhi persepsi masyarakat tentang krisis tersebut (Puspitasari, 2016). Kritik terhadap pemberitaan bencana antara lain beritaberita terlalu mengeksploitasi kesedihan, tidak akurat, dan dramatisasi. Oleh karena itu, berita-berita positif seperti kekuatan solidaritas masyarakat, upaya progresif pemerintah mencegah gelombang kemiskinan baru, dan kesembuhan membantu memberikan harapan bagi masyarakat, dengan menyuguhkan berbagai solusi praktis yang secepatnya bisa dilakukan, perlu untuk dikedepankan (Nazaruddin, 2007; Parahita, 2020).

\section{Metode}

Penelitian ini menggunakan metode kualitatif dengan teknik pengumpulan data berupa wawancara. Narasumber penelitian adalah perwakilan dari redaksi media yakni Kompas.com, Liputan6.com, Republika, Kedaulatan Rakyat Group, dan Solopos.com (Catatan : nama narasumber, jabatan, teknik wawancara, dan waktu wawancara dapat dibaca di Tabel 1). Sebelumnya, peneliti mengirimkan permohonan izin wawancara ke 16 media massa (baik lokal mau pun nasional). Selanjutnya delapan media menyatakan kesediaan diwawancarai. Dari delapan media, lima media memberikan keterangan paling lengkap mengenai kebijakan redaksional dalam pemberitaan batalnya pemberangkatan jamaah haji Indonesia tahun 2020 
Pengambilan data berlangsung saat Covid-19 sehingga pemerintah menganjurkan untuk meminimalkan pertemuan tatap muka . Hal ini membuat wawancara berlangsung secara tertulis menggunakan media surat elektronik (peneliti mengirim daftar pertanyaan dan narasumber membalas) atau percakapan melalui telepon. Perbincangan lewat telepon direkam atas persetujuan narsumber. Hanya ada satu narasumber yang meminta wawancara dilakukan secara tatap muka

Wawancara melalui telepon atau menggunakan surat elektronik memiliki keuntungan karena peneliti bisa mewawancarai narasumber yang berada di lokasi berbeda, tanpa harus bertemu langsung. Sebagai tambahan, keuntungan wawancara melalui surat elektronik adalah narasumber bisa lebih fokus dan memiliki waktu untuk memikirkan dan mempertimbangkan jawaban yang disampaikan. Jawaban secara tertulis juga memungkinkan informasi yang lebih terstruktur. Meski begitu kelemahannya adalah faktor jarak bisa mempengaruhi relasi interpersonal antara pewawancara dengan narasumber, sehingga ada kesulitan untuk menggali fakta lebih dalam (Block \& Erskine, 2012; Ratislavová \& Ratislav, 2014).

Tabel 1. Daftar Narasumber

\begin{tabular}{|l|l|l|l|l|}
\hline No. & Nama Narasumber & $\begin{array}{l}\text { Jabatan narasumber*/ } \\
\text { nama media }\end{array}$ & $\begin{array}{l}\text { Teknis } \\
\text { wawancara }\end{array}$ & Waktu wawancara \\
\hline 1 & Rini Yustiningsih & $\begin{array}{l}\text { Pemimpin Redaksi/ } \\
\text { Solopos.com }\end{array}$ & $\begin{array}{l}\text { Surat } \\
\text { elektronik }\end{array}$ & $\begin{array}{l}\text { 13 Juli 2020 } \\
\text { (tanggal saat } \\
\text { balasan diterima } \\
\text { peneliti) }\end{array}$ \\
\hline 2 & Amir Sodiqin & $\begin{array}{l}\text { Redaktur Pelaksana/ } \\
\text { Kompas.com }\end{array}$ & Telepon & 5 Agustus 2020 \\
\hline 3 & Muhammad Hafil & $\begin{array}{l}\text { Editor desk "Khazanah"/ } \\
\text { Republika }\end{array}$ & Telepon & 11 Agustus 2020 \\
\hline 4 & $\begin{array}{l}\text { Raden Trimutia } \\
\text { Hatta }\end{array}$ & $\begin{array}{l}\text { Redaktur Pelaksana/ } \\
\text { Liputan6.com }\end{array}$ & $\begin{array}{l}\text { Surat } \\
\text { elektronik }\end{array}$ & $\begin{array}{l}\text { 11 Agustus 2020 } \\
\text { (tanggal saat } \\
\text { balasan diterima } \\
\text { peneliti) }\end{array}$ \\
\hline 5 & $\begin{array}{l}\text { Drs H. Ahmad } \\
\text { Lutfi, MA }\end{array}$ & $\begin{array}{l}\text { Wakil Pemimpin Redaksi/ } \\
\text { Kedaulatan Rakyat Group }\end{array}$ & Tatap muka & 13 Agustus 2020 \\
\hline
\end{tabular}

*) Catatan : jabatan saat wawancara dilakukan 


\section{Hasil dan pembahasan}

Hasil penelitian dibagi berdasarkan berdasarkan poin-poin dari konsep kebijakan redaksional yakni : (1) pemilihan topik/ isu/ peristiwa dan (2) sumber berita, dan teknik liputan berita (Abrar, 2019; Eriyanto, 2002; Gonzales, 2017; Kedoh, 2018). Guna memperoleh gambaran kebijakan masing-masing media, maka dalam bagian ini disajikan hasil wawancara per media

1. Pemilihan topik, isu atau peristiwa

Secara umum kelima media memberitakan hal-hal yang berkaitan dengan nasib jamaah haji asal Indonesia, media mengangkat tema tentang kepastian haji tahun ini dan rencanarencana yang disiapkan pemerintah RI untuk mengantisipasi segala kemungkinan, sebelum adanya pengumuman resmi berkaitan dengan pelaksanaan haji. Ada pun setelah pemerintah RI memastikan tidak memberangkatkan jamaah haji asal Indonesia, media mengangkat tema mengenai prosedur pengembalian uang pelunasan ibadah haji bagi jamaah yang gagal berangkat. Beberapa media memiliki kebijakan khusus seperti memberitakan hal-hal yang tidak menimbulkan kepanikan atau spekulasi di masyarakat.

a. Republika.co.id

Topik utama yang diangkat media ini adalah seperti informasi mengenai kepastian haji, situasi terkini di Arab Saudi, teknis pengembalian uang jamaah, dan juga artikel keagamaan/sejarah mengenai kegiatan haji di masa lampau apakah pernah gagal terlaksana atau tidak, yang dikaitkan dengan keadaan saat Kementrian Agama masih belum memastikan apakah jamaah Indonesia haji tahun ini aka berangkat atau tidak.

"Terbukti di saat Covid ketika haji "ditiadakan" tapi kita masih terus memproduksi berita tentang haji. Sebelum Arab memutuskan dan pemerintah belum memutuskan... Di dalam negeri teknis pengembalian uang jamaah, teknis pendaftaran tahun depan, nasib manasik haji jamaah, pelunasan itu kita angkat....Kita angkat pembukaan Masjidil Haram, informasi jam malam, jam malam di Madinah. Haji kaitannya di Jeddah, Makkah, Madinah. Selain itu kebijakan tadi, lainnya artikel keagamaan...bagaimana sejarah haji dibatalkan tahun berapa aja,. Indonesia (pernah dibatalkan-pen) tahun berapa aja." (Muhammad Hafil)

Selanjutnya, setelah Kemenag RI mengeluarkan pengumuman, berita yang diangkat adalah mengenai pengembalian uang jamaah karena urgensinya sangat mendesak mengingat jamaah membutuhkan kepastian akan dana itu. Lalu ada juga berita sampingan mengenai kondisi jamaah haji di negara lain dan nasib perusahaan travel. Narasumber menuturkan :

"Yang paling awal sekali tentu peristiwanya. Tentu kita membandingkan dengan jamaah negara lain....Selain itu juga nasib perusahaan travel kita angkat juga...bahkan pegawai-pegawainya menerima bantuan BPKH."," (Muhammad Hafil)

Pengumuman Kemenag RI memunculkan sejumlah perdebatan, 
bahkan adakalanya beredar isu liar berkaitan dengan pengembalian uang jamaah haji dan juga pihak-pihak terdampak akibat pembatalan ini seperti pihak travel haji. Pemberitaan Republika.co.id berkaitan dengan isu tersebut adalah menjelaskan bagaimana keadaan yang sebenarnya

"Yang paling hangat yang diangkat soal pengembalian uang jamaah. Kalau tidak teliti, akan muncul kesan dana jamaah haji nggak dibalikin. Dana jamaah kan ada dari APBN dan ada yang bayar sendiri. Orang mengiranya akan mengalihkan dana haji itu untuk Covid, orang menyangkanya itu uang jamaah. Itu isu yang seksi, apalagi waktu itu BPKH sempat ngomong dana jamaah haji untuk Covid." (Muhammad Hafil)

Narasumber menegaskan bahwa kebijakan redaksional Republika.co.id pasca pengumuman pemerintah RI pembatalan pemberangkatan jamaah haji asal Indonesia adalah mengusung misi agar masyarakat tidak panik.

"Lebih penekanan ketenangan pada jamaah. Ada tuntutan juga untuk menenangkan jamaah. dia itu menenangkan. Kita membangun simpati, ada goals untuk menenangkan. Fungsi edukasi termasuk di situ." (Muhammad Hafil)

\section{b. Kompas.com}

Ketidakpastian mengenai pelaksanaan ibadah Haji tahun 2020 disadari Kompas.com akan menuai banyak tanggapan, sehingga Kompas memutuskan hanya mengangkat beritaberita yang merupakan pengumuman resmi dari otoritas yang berwenang, dan bukan pernyataan-pernyataan yang bisa membingungkan atau malah menimbulkan perdebatan di masyarakat.

"Untuk pandemi Kompas.com punya rules tidak membuat berita yang sifatnya belum pasti dan sensasional terus memicu kepanikan....misal mengimbau pemerintah menghentikan atau mengimbau pemerintah berjuang meloloskan.... Itu kita hindari. Selama belum ada pengumuma kita tidak berani bikin berita spekulasi. Kita tidak dibolehkan bikin berita sifat agitatif untuk kepentingan entah meloloskan atau menghentikan haji... Kita betul-betul ingin memberi kepastian pada masyarakat, mau diberangkatkan atau tidak, based on keputusan final dari pemerintah." (Amir Sodiqin)

Pasca pengumuman dari Kemenag RI, Kompas.com menyajikan berita seputar prosedur-prosedur untuk jemaah yang telah mendaftar haji tahun ini, dan informasi lain seputar keputusan Kemenag. Seperti dituturkan narausmber,

"Teknis informatif bagi yang sudah bayar ibadah haji, seperti apa; bagi yang ingin refund sepeti apa prosedurnya, itu yang kita beritakan (Amir Sodiqin).

Narasumber menambahkan bahwa Kompas.com tidak memberikan informasi yang membuka celah masyarakat atau pihak lain untuk berdiksusi terkait keputusan yang sudah ditetapkan Kemenag RI

"Setelah pengumuman dari Kementerian Agama dan itu sudah 
dipastikan bahwa presiden juga menghendaki seperti itu, kita tidak membuka ruang diskusi, seperti berita tentang pernyataan politisi misal mendorong pemerintah jangan langsung ditutup" (Amir Sodiqin).

Perubahan situasi ini mempengaruhi rencana media dalam liputan haji karena update berita lebih lambat dari biasanya dikarenakan keputusan dari Arab Saudi dan Kemenag RI yang sangat ditunggu. Narasumber penelitian mengatakan : "update as usual, tetapi tidak sekencang biasanya...Tidak seperti liputan ibadah haji, tidak banyak ekspos." (Amir Sodiqin)

\section{c. Liputan6.com}

Liputan6.com menyajikan topik terkait dengan covid-19 bagi jamaah haji dan perubahan-perubahan apa saja yang berbeda dari haji biasanya, serta kisah jamaah haji Indonesia yang terpilih beribadah pada 2020.

"Seputar penerapan protokol kesehatan COVID-19 bagi jamaah haji, dan perubahan-perubahan apa saja yang berbeda dari haji biasanya, serta kisah-kisah jamaah haji Indonesia yang terpilih beribadah pada 2020.” (R Trimutia Hatta)

Kemudian setelah Kemenag RI mengeluarkan pengumuman, Liputan6.com memberitakan informasi seputar alasan pembatalan haji, nasib jamaah calon haji, dan tanggung jawab pemerintah terkait dengan jamaah yang batal diberangkatkan.

Pembatalan pemberangkatan haji asal Indonesia ini mempengaruhi rencana Liputan6.com karena sebelumnya sudah menyiapkan rancangan kanal khusus haji. Guna merespon keadaan tersebut, tim Liputan6.com melakukan perubahan pada rubrikasi.

"Sudah merancang seperti tahun-tahun sebelumnya....kanal khusus yang menyediakan berita seputar haji sejak sebelum keberangkatan jamaah, puncak haji, hingga kepulangan Jemaah ke Tanah Air. Namun karena ada pembatalan, pemberitaan seputar Haji 2020 tidak dimuat di kanal khusus Haji melainkan di kanal Global/Internasional untuk seputar berita penyelenggaraan haji dengan sumber dari Arab Saudi dan kanal News/Nasional untuk pemberitaan dengan sumber dari Kemenag” ( $R$ Trimutia Hatta)

\section{d. Solopos.com}

Narasumber dari Solopos.com menjelaskan, bahwa sebelum adanya informasi pengumuman resmi dari Kemenag RI dan pemerintah Arab Saudi, media ini mengangkat berita-berita mengenai kuota haji, daftar tunggu haji, biaya penyelenggaraan ibadah haji, pelunasan haji, dan juga beberapa kebijakan baru pemerintah mengenai haji seperti zonasi dan manasik haji.

Pasca pengumuman dari Kemenag RI, Solopos.com memberitakan informasi berkaitan dengan teknis pembatalan, nasib calon jemaah haji, pengembalian uang pelunasan, kisah jemaah calon haji yang batal berangkat dan lainnya. Ada pun narasumber resmi dari Kementerian Agama berfungsi untuk informasi mengenai apa langkah-langkah selanjutnya yang akan dilakukan.

"Beberapa tema liputan setelah ada pembatalan adalah teknis 
pembatalan, nasib calon jemaah haji, pengembalian uang pelunasan, kisah jemaah calon haji yang akhirnya batal berangkat, dan lainnya. Informasi yang diberikan narasumber sesuai proporsi mereka...bagi pejabat kantor kementerian agama memberikan tanggapan atau langkah yang diambil setelah ada pembatalan haji” (Rini Yustiningsih).

Pemberitaan berkaitan dengan human interest juga diangkat oleh Solopos.com, misal tentang nasib jamaah haji yang gagal berangkat, atau bagaimana nasib bisnis di kawasan sekitar embarkasi Donohudan pasca pembatalan keberangkatan jamaah haji asal Indonesia

"Tema human interest ini menarik bagi pembaca.... misalnya jemaah calon haji yang batal berangkat diulas tentang kisah mereka dan langkah mereka seperti apa.....Sedangkan dampak pembatalan terhadap bisnis warga di sekitar embarkasi. Di sekitar Embarkasi Donohudan Boyolali, biasanya rame oleh bisnis dari mulai jual beli barang hingga jasa. Hal itu tak ada tahun ini". (Rini Yustiningsih)

Perubahan situasi ini mempengaruhi rencana media dalam liputan haji. Solopos.com selanjutnya melakukan perubahan berkaitan tema berita dan teknis peliputan berita berkaitan dengan haji. Pihak Solopos.com juga menyatakan bahwa teknik liputan yang dilakukan adalah menggunakan hasil liputan wartawan Solopos, dan menggunakan sumber sekunder seperti media resmi Kementerian Agama dan kantor berita lain.

"Bagaimana pun berita haji itu tetap menarik bagi pembaca muslim maupun keluarga calon haji maupun yang sudah pernah berhaji. Biasanya berita haji dan Covid tetap kami sampaikan, bagaimana pelaksanaan haji yang hanya menyertakan warga setempat dan ekspatriat di Arab Saudi....Kami mengolah berita hanya dari Kemenag, jemaah calon haji, dan pemerintah. Kami mengolah informasi lain soal haji misalnya nasib calon haji, dana haji daerah, pengembalian biaya haji, dsb. Selain materi liputan dari reporter, sumber lain dalam berita haji berasal dari newswire atau mengambil pernyataan Kemenag di laman resmi mereka." (Rini Yustiningsih)

\section{e. Kedaulatan Rakyat (KR) Group}

Sebelum adanya pengumuman resmi berkaitan dengan haji, media KR mengangkat berita-berita mengenai rencana yang dibentuk Kemenag RI mengenai keputasan haji yang akan terjadi pada tahun 2020

"Ketika belum ada kepastian, kita memberitakan renana-rencana dari Kemenag. Kalau persiapan tetap memberitakan, kita muat dulu. Lalu Kemenang nunggu tanggal sekian, kok belum ada keputusan, sampai akhirnya Kemenag press conference pembatalan berangkat, kita muat besar-besaran ya." (H.Ahmad Lutfi)

Perubahan situasi dalam pelaksanaan haji tahun 2020 tidak memengaruhi rencana media dalam liputan haji karena 
KR tidak merancang rubrik khusus. Berita tentang pelaksanaan ibadah haji tetap disajikan, dengan sumber mengutip dari kantor berita lain.

"Untuk 2020 ini KR tidak merancang rubrik khusus, tapi berita haji tetap ada. Seperti kemarin ketika haji maksimal 10 ribu orang, kita muat. Misal pas tawaf foto di Ka'bah itu kita jadikan headline. Sumber dari kantor berita, karena peliput khusus tidak bisa di sana. Jadi dari Arab Saudi membentuk tim peliput." (H. Ahmad Lutfi)

2. Penggunaan Sumber berita dan Teknik Liputan

Secara umum kelima narasumber mengatakan sumber berita utama dalam liputan haji tahun 2020 adalah Kemenag RI baik itu yang di tingkat pusat mau pun di daerah. Sumber selanjutnya adalah jamaah haji dan travel agen. Cara meliput berita dilakukan dengan cara melakukan wawancara langsung ke narasumber - di masa pandemic menggunakan , mengutip dari informasi yang ada di laman resmi otoritas resmi, atau mengutip dari pemberitaan media massa lain.

a. Republika.co.id

Republika.co.id menggunakan narasumber jamaah haji, otoritas resmi Indonesia (Kemenag RI dan perwakilan RI di Saudi Arabia), dan penyelenggara haji berbagai negara.

"Wawancara dengan calon jamaah banyak sekali yang kita wawancara, yang sudah ngumpulin uang, ngantri 8 tahun, dari daerahdaerah. Baik jamaah yang diwakili sendiri. Kita pantau situs-situs penyelenggara haji berbagai negara, mereka bagaimana nih pengumumannya. Kita pantau dari Arab Saudi, KJRI dari Kementerian Haji”. (Muhammad Hafil)

Sumber sekunder berupa buku digunakan untuk mendukung artikel tentang catatan sejarah yang berkaitan dengan pembatalan ibadah haji.

“...artikel keagamaan, dari buku Kemenag mau pun manasik haji di situ bagaimana sejarah haji dibatalkan tahun berapa aja gitu kan. Indonesia tahun berapa aja." (Muhammad Hafil)

Kriteria narasumber adalah yang terpercaya dan kredibel dalam urusan haji. Sumber dari Kemenag, Dirjen Haji, dan Direktur Haji merupakan narasumber wajib yang harus didapatkan informasinya. Sumber lain bisa didapat dari Lembaga Swadaya Masyarakat, Komnas Haji, pewakilan RI di Arab Saudi, biro travel.

"Kemenag yang paling primer Menteri Agama, Dirjen Haji, Direktur Haji baik dalam negeri mau pun luar negeri, haji khusus dan umroh. Kemudian kita wawancara juga dari travel dari AMPHURI, asosiasi penyelenggara haji umroh Indonesia. Dari LSM ada Komnas Haji . Dari masyarakatnya. Dari ormas Islam, dari DPR Komisi Agama kita wawancara semua. KJRI juga ada Konjen Teknis Urusan Haji. Dubes juga mantau, walau di Riyadh posisinya.Kepala Daerah kan jadi Amirul Hajj di propinsinya (Muhammad Hafil)

Republika juga menggunakan informasi yang ada situs web resmi dari Kemenag, meski bukan menjadi prioritas 
utama. Wartawan Republika menindaklanjuti informasi yang ada di situs web dengan melakukan wawancara. “....website terbuka untuk publik. Tapi kalau sebagai media, kurang kredibel kalau mengutip, kecuali penting banget. Sepertinya nggak enak jika pada berita ditulis : dikutip laman Kemenag, karena yang disampaikan di website resmi, informasi yang bagus-bagus saja Jadi sebisa mungkin kita kontak balik." (Muhammad Hafil)

b. Kompas.com

Narasumber dari Kompas.com menyatakan bahwa sumber berita liputan haji ini adalah Kemenag, travel, biro perjalanan dan pihak lain yang berkaitan dalam proses haji. Kompas bermaksud untuk memnberikan informasi yang transparan kepada pembaca guna menghindari benturan antara berbagai pihak.

"Jadi kita menjembatani pemerintah, biro travel, warga. Ketiganya ini punya kebutuhan informasi yang berbedabeda....Pemerintah baca, beri feedback, sudah jadi keputusan diakses warga terdampak. Sehingga meminimalkan benturan tiga pihak. Mereka welcome karena butuh publikasi. Media dalam situasi seperti itu justru jadi semacam penengah untuk menyampaikan keluhan, protes, kita malah dibutuhkan di situasi seperti itu." (Amir Sodiqin)

Kompas.com tidak menggunakan sumber berita yang tidak memiliki kewenangan dalam memutuskan soal haji.
"Kita betul-betul nunggu dari otoritas terkait, sikap RI atau sikap pemerintah Arab Saudi seperti apa. Kalau ada politisi ngomong $A, B, C$ mendorong atau mengimbau yang sifatnya agitatif, tidak kita beritakan" (Amir Sodiqin)

Teknik liputan Kompas.com di masa pandemic ini banyak memanfaatkan teknologi komunikasi untuk wawancara jarak jauh dan mengutip dari kantor berita lain.

Webinar, teleconference, kita banyak memanfaatkan outlet itu...kita beritakan dari wire-wire yang ada, dari media-media lokal di sana (Arab Saudi-pen) terkait ibadah haji. Sampai Idul Qurban juga kita beritakan. (Amir Sodiqin)

c. Liputan6.com

Liputan6.com melalui jawaban tertulis kepada peneliti menjelaskan bahwa setelah adanya keputusan pembatalan pemberangkatan haji, narasumber yang dipilih adalah, Menteri Agama Fachrul Razi, anggota DPR RI, dan jamaah yang gagal berangkat haji 2020. Media tersebut mengaku lebih memilih melakukan wawancara kepada narasumber yang kredibel dan mengutip berita yang resmi dirilis oleh Kemenag dan kantor berita Antara.

\section{d. Solopos.com}

Solopos.com dalam jawaban secara tertulis yang diterima peneliti menjelaskan pemilihan narasumber pemberitaannya didasari dengan tema yang diangkat. Berkaitan dengan pembatalan pemberangkatan haji, maka narasumber adalah pejabat kementerian agama dan calon jamaah haji. 
"Penilaian media terhadap narasumber dilihat dari kualitas informasi yang diberikan dimana narasumber memberi sesuai porsi mereka bagi pembaca. Sedangkan bagi pejabat kantor kementerian agama memberikan tanggapan atau langkah yang diambil setelah ada pembatalan haji." (Rini Yustiningsih)

Ada pun sumber berita yang digunakan Solopos.com adalah : “...materi dari reporter Solopos, sumber lain dalam berita haji berasal dari newswire atau mengambil pernyataan Kementerian Agama di laman resmi mereka." (Rini Yustiningsih)

\section{e. Kedaulatan Rakyat Group}

Setelah pengumuman dari kemenag RI, KR Group menyajikan berita dengan memilih narasumber dari Kemenag baik di tingkat pusat mau pun daerah, serta komentar dari masyarakat berkaitan dengan uang pelunasan.

"Yang kita beritakan Kemenag pusat, sumber dari Menteri Agama, Wakil Menteri, atau Dirjen. Kalau berita di pusat, KR ada kantor perwakilan di Jakarta. Setelah pengumuman, kita angkat komentarkomentar dari masyarakat jamaah haji, terus dari Kabid PHU Kanwil Yogya itu kita muat" (H. Ahmad Lutfi)

Pihak KR Group menilai narasumber berita menyampaikan informasi dengan cepat. Kedekatan personal dengan narasumber di tingkat pusat memudahkan KR Group dalam memperoleh informasi.. Kekurangannya adalah detil informasi yang masih kurang.
"Akses informasi ke narasumber, itu mudah. Dari segi respon informasi cepat... Kebetulan dengan Dirjen Kemenag RI kita kenal baik, orang Yogya....Pejabat Kemenag juga pengen menyampaikan ke masyarakat. Dengan diwawancara, diberitakan media, Kemenag terbantu untuk menyampaikan itu. Kekurangannya kadang informasinya tidak seperti yang kita inginkan. Kita ingin banyak tapi di sana yang ada sedikit. Kelebihannya, itu bisa dikatakan resmi pemerintah." (H. Ahmad Lutfi).

\section{Pembahasan}

Kebijakan redaksional adalah pedoman operasional pemberitaan di sebuah media dalam penentukan isu dan sudut pandang liputan, isi dan nilai berita, pemilihan narasumber, penugasan, pemformatan berita, penyuntingan berita, penyajian berita termasuk juga pengelompokan berita berdasarkan rubrik atau program tertentu (Abrar, 2019; Gonzales, 2017; Kedoh, 2018). Berdasarkan hasil temuan yang didapatkan, terdapat beberapa hal yang menjadi poin penyesuaian dan pertimbangan kebijakan redaksi yang dilakukan oleh media-media yang diteliti dalam pemberitaan pembatalan pemberangkatan jemaah haji 2020.

Sebelum pengumuman resmi kepastian haji, kelima media pada umumnya mengangkat berita-berita mengenai kepastian haji, teknis pengembalian uang haji, hal-hal yang berubah dari pelaksanaan haji tahun 2020 dan rencana-rencana Kemenag sembari menunggu kepastian mengenai haji. Ada pun narasaumber yang digunakan adalah 
dari pihak otoritas dan masyarakat calon jamaah haji.

Selanjutnya saat pengumuman resmi tentang kepastian ibadah haji tahun 2020 -- baik dari pemerintah RI tentang pembatalan pemberangkatan haji dan pemerintah Kerajaan Saudi Arabia disampaikan kelima media secara umum mengangkat mengenai tentang apa yang selanjutnya harus dilakukan oleh jamaah terutama mengenai teknis pengembalian pelunasan uang haji. Temuan ini senada dengan literatur yang menyebutkan bahwa dalam situasi krisis, media memiliki peran untuk menginformasikan kepada masyarakat tentang apa yang terjadi, apa dampak bagi masyrakat dan apa yang harus dilakukan (Puspitasari, 2016). Lebih jauh, dengan mengadopsi konsep tahapan normatif pemberitaan mengenai bencana (Nazaruddin, 2007), maka informasi yang disampaikan adalah informasi dasar dan akurat mengenai bencana tersebut, upaya-upaya untuk menyelamatkan, dan cara-cara dalam mengakses bantuan - dalam konteks haji ini adalah teknis pengembalian uang pelunasan haji

Ada beberapa ciri khas dari peliputan media tersebut, misalnya Republika memiliki misi untuk menyajikan pemberitaan yang bersifat "menenangkan" masyarakat. Sementara Kompas memutuskan tidak akan memberitakan pernyataan yang bukan berasal dari otoritas resmi - dalam hal ini pemerintah. Pasalnya, dalam situasi krisis, arus informasi akan mengalami peningkatan yang luar biasa karena publik ingin tahu apa yang terjadi, sementara di sisi lain situasi krisis juga dapat menimbulkan spekulasi yang disebarkan oleh orang yang tidak paham atau yang sengaja untuk menebar informasi yang salah untuk memperkeruh situasi (Prastya \& Utami, 2020).

Sementara dari media lokal, Solopos juga menghadirkan berita bertema human interest jamaah yang gagal berangkat dan bagaimana geliat bisnis di sekitar embarkasi haji Donohudan pasca pembatalan pemberangkatan jamaah haji Indonesia. Berita-berita seperti ini penting untuk memulihkan kondisi salah satunya psikologis masyarakat. beritaberita positif seperti kekuatan solidaritas masyarakat, upaya progresif pemerintah dalam mengatasi persoalan, dan hal-hal yang menumbuhkan harapan (Parahita, 2020). Sebaliknya, berita-berita yang kontraproduktif dengan cenderung menampilkan hal-hal traumatis dan dramatis harus diminimalkan (Nazaruddin, 2007).

Media menggunakan sumber primer dan sumber sekunder sebagai sumber informasi/berita. Sumber primer adalah pihak yang terlibat langsung dengan peristiwa sehingga dapat memberikan pandangan atau pendapatnya tentang peristiwa atau isu yang diberitakan, antara lain saksi mata dari sebuah peristiwa, pencipta dari sebuah karya, pimpinan organisasi, juru bicara organisasi, asosiasi, tokoh politik dan sosial dan otoritas pemerintah. Idealnya, sumber primer harus diwawancarai secara langsung baik itu tatap muka atau menggunakan media komunikasi seperti telepon, Skype, atau fitur-fitur percakapan lainnya (Tate \& Taylor, 2014).

Sumber primer dalam liputan haji adalah otoritas pemerintahan RI seperti Kementerian Agama dan perwakilan pemerintah RI di Arab Saudi, calon jamaah haji, dan travel penyedia layanan haji dan umrah. Sehubungan dengan 
masa pandemi, teknik wawancara dilakukan dengan teleconference, mengikuti webinar yang diselenggarakan narasumber.

Sumber sekunder berasal dari tangan kedua yang dapat memberikan informasi faktual kepada wartawan, misalnya adalah buku referensi, sumber-sumber dari pemerintah yang dipublikasikan, dan situsweb/sumber dari internet yang memiliki kredibilitas (Tate \& Taylor, 2014).

Sumber sekunder dalam temuan penelitian ini adalah situsweb/laman resmi dari otoritas haji baik di Indonesia mau pun Arab Saudi dan kantor berita lain. Dalam menggunakan informasi dari situs web resmi, media tidak serta merta menggunakan informasi yang ada, namun juga menggali informasi lebih lanjut dengan menghubungi narasumber. Satu media yakni Republika juga menggunakan buku sebagai sumber informasi.

Situs web resmi merupakan media komunikasi yang dapat dimanfaatkan organisasi untuk menyampaikan informasi kepada media di kala krisis, secara lebih efektif dan efisien Lewat situsweb resmi, organisasi dapat memgklatifikasi informasi yang salah (Prastya \& Utami, 2020). Meski begitu media massa memang belum tentu mengutip pernyataan resmi dari organisasi seperti apa adanya, karena media massa sudah memiliki pertimbangan tersendiri untuk informasiinformasi yang diangkat atau pun tidak (Dewabroto, 2014; Eriyanto, 2002). Dengan begitu redaksi media akan memilih informasi mana yang akan dimuat, mana yang akan tidak, atau akan melakukan wawancara lanjutan berdasarkan informasi yang tercantum pada situs web resmi organisasi.

Penggunaan kantor berita sebagai sumber berita menjadi keniscayaan terlebih di era internet seperti saat ini. Dengan mengutip dari kantor berita lain, media dapat memperoleh informasi dengan cepat dan dari informasi yang berasal dari tempat yang jauh (secara geografis) dengan kantor media tersebut.

Studi di Australia menyatakan bahwa media online sangat bergantung pada berita-berita dari kantor berita. Ini disebabkan iklim media online yang menuntut update setiap waktu, membutuhkan berita dalam kuantitas yang besar. Kepercayaan wartawan Australia terhadap kantor berita disebabkan karena informasi yang cepat update dan kredibilitas informasi dapat dipertanggungjawabkan (Johnston \& Forde, 2009). Studi lain di Amerika Serikat menyebutkan bahwa wartawan media lokal menggunakan informasi dari kantor berita untuk informasi mengenai pemerintah pusat. Bahkan hal ini juga dilakukan oleh media lokal yang menempatkan koresponden di Washington (Pew Research Center, 2015).

\section{Kesimpulan}

Kebijakan redaksional media massa berkaitan dengan tema berita, narasumber dan teknis penelitian. Sebelum pengumuman resmi kepastian haji, kelima media pada umumnya mengangkat berita-berita mengenai kepastian haji, teknis pengembalian uang haji, hal-hal yang berubah dari pelaksanaan haji tahun 2020 dan rencanarencana Kemenag sembari menunggu kepastian mengenai haji. Saat sudah ada kepastian tentang pelaksanaan haji tahun 
2020, media memberitakan mengenai tentang apa yang selanjutnya harus dilakukan oleh jamaah terutama mengenai teknis pengembalian pelunasan uang haji.

Keputusan pemerintah RI tidak memberangkatkan jamaah asal Indonesia menimbulkan berbagai pandangan di masyarakat dan spekulasi bermunculan. Media memutuskan tidak mengangkat pandangan-pandangan ini karena dikhawatirkan dapat menimbulkan keresahan di masyarakat. Selain itu beberapa media juga menyajikan berita khas seperti pengetahuan tentang sejarah haji dan bagaimana nasib bisnis di kawasan embarkasi haji.

Sumber berita utama dalam liputan haji tahun 2020 adalah Kemenag RI baik itu yang di tingkat pusat mau pun di daerah. Sumber selanjutnya adalah jamaah haji dan agen travel. Cara meliput berita dilakukan dengan cara melakukan wawancara langsung ke narasumber secara daring/online. Cara selanjutnya adalah menggunakna sumber sekunder yakni mengutip dari informasi yang ada di laman resmi otoritas resmi, atau dari pemberitaan media massa/kantor berita lain.

Keterbatasan penelitian ini, pertama jumlah media yang diwawancarai hanya lima, sehingga hasil penelitian ini masih bersifat temuan awal. Kedua, wawancara dengan mayoritas narasumber penelitian hanya dapat dilakukan melalui telepon atau surat elektronik akibat kondisi Covid-19. Di satu sisi cara ini memang bisa memudahkan menjangkau narasumber di lokasi yang berbeda, tapi di sisi lain ada keterbatasan dalam interaktifitas sehingga untuk menggali informasi tidak bisa sebaik saat pertemuan tatap muka.
Saran untuk penelitian selanjutnya, pertama membahas tentang pemberitaan media mengenai ibadah haji tahun 2020 dengan menggunakan metode analisis isi (kuantitatif atau kualitatif) untuk mengetahui bagaimana kecenderungan, objektivitas, frame, atau narasi yang ditawarkan oleh media. Kedua adalah penelitian yang membahas kebijakan redaksi media mengenai keputusankeputusan pemerintah berkaitan dengan kegiatan keagamaan di masa Covid-19.

\section{Referensi}

Abrar, A. N. (2019). Menatap Masa Depan Jurnalisme Indonesia. Gadjah Mada University Press. Alqahtani, A. S., Wiley, K. E., Willaby, H. W., BinDhim, N. F., Tashani, M., Heywood, A. E., Rashid, H. (2015). Australian hajj pilgrims' knowledge, attitude and perception about ebola, november 2014 to february 2015. Eurosurveillance, 20(12), 1-4. https://doi.org/https://doi.org/Http: //10.2807/15607917.ES2015.20.12.21072

Block, E. S., \& Erskine, L. (2012). Interviewing by telephone: Specific considerations, opportunities, and challenges. International Journal of Qualitative Methods, 11(4), 428445.

https://doi.org/https://doi.org/10.1 177/160940691201100409

Caidi, N. (2019). Pilgrimage to Hajj : An Information Journey. The International Journal of Information, Diversity, and Inclusion, 3(1), 44-76. https://doi.org/https://doi.org/10.3 3137/ijidi.v3i1.32267

Center, P. R. (2015). Today's Washington Press Corps More 
Digital, Specialized. Retrieved

from

https://www.pewresearch.org/wp-

content/uploads/sites/8/2015/12/PJ

_2015-12-03_Washington-Press-

Corps_FINAL.pdf

Dewabroto, G. S. (2014). Tantangan

Public Relations di Era

Keterbukaan Informasi Publik.

Gramedia Pustaka.

Eriyanto. (2002). Analisis Framing:

Konstruksi, Ideologi, dan Politik

Media. LKiS.

Gonzales, M. F. G. (2017). The newsroom: a space of decision making. In Peter Lang.

Hadi, S. (2015). Komodifikasi berita penyelenggaran ibadah haji di SKH republika. Alhadharah Jurnal Ilmu Dakwah, 14(27), 5155.

https://doi.org/10.18592/alhadhara h.v14i27.1226

Johnston, J., \& Forde, S. (2009). Not wrong for long: the role and penetration of news wire agencies in the 24/7 news landscape. Global Media Journal Australian Edition, 3(2), 1-15.

https://doi.org/http://search.ebscoh ost.com/login.aspx?direct=true\&d $\mathrm{b}=\mathrm{ufh} \& \mathrm{AN}=49765562 \&$ lang $=\mathrm{es} \&$ site $=$ ehost-live

Kasman, S. (2019). Tradisi jamaah haji orang bugis sepulang dari tanah suci Mekah (Perspektif Kompas TV Makassar). Jurnalisa, 5(2), 241-261.

https://doi.org/https://doi.org/10.2 4252/jurnalisa.v5i2.11958

Kedoh, L. N. (2018). Kebijakan redaksional surat kabar flores pos dalam mempertahankan eksistensi. Jurnal Nomosleca, 4(2), 805-811. https://doi.org/https://doi.org/http:/ /10.26905/nomosleca.v4i2.2547

Mabruroh. (2020). Arab Saudi Batasi Jamaah Haji Kurang dari 1000 orang. Retrieved from Ihram.Co.Id website: https://ihram.co.id/berita/qcekad45

9/arab-saudi-batasi-jamaah-hajikurang-dari-1000-orang

Mongglio, Z. M. . (2020). Jurnalis Indonesia di Masa Pandemi Covid-19 : Kisah Profesi dan Catatan Harapan. In Media, Komunikasi, dan Informasi di Masa Pandemi Covid-19. Yogyakarta: MBridge Press.

Nazaruddin, M. (2007). Jurnalisme bencana: sebuah tinjauan etis. Jurnal Komunikasi, 1(2), 163-177. Parahita, G. D. (2020). Lima Dimensi Jurnalisme Krisis COVID-19. In Tata Kelola Penanganan COVID19 di Indonesia. Gadjah Mada University Press.

Pers Dewan. (2020). No. 4.

Prastya, N. ., \& Utami, N. . (2020). Analisis Pesan Komunikasi Krisis Kementerian Agama RI di Masa Pandemi Covid-19 (Kasus Pembatalan Pemberangkatan Jamaah Haji Indonesia. In Media, Komunikasi, dan Informasi di Masa Pandemi Covid-19. Yogyakarta: MBridge Press.

Puspitasari. (2016). Komunikasi Krisis: Strategi Mengelola dan Memenangkan Citra di Mata Publik. Penerbit Libri.

Ratislavová, K., \& Ratislav, J. (2014). Asynchronous email interview as a qualitative research method in the humanities. Human Affairs, 24(4), 452-460. https://doi.org/https://doi.org/10.2 478/s13374-014-0240-y

Rochyadi-Reetz, M., Maryani, E., \& Agustina, A. (2020). Media use and gratification sought by the public during the coronavirus outbreak in Indonesia. Jurnal Komunikasi Ikatan Sarjana Komunikasi Indonesia, 5(1), 111124.

Tate, C. ., \& Taylor, S. . (2014). Scholastic Journalism, Twelve Edition. West-Sussex. UK: Wiley. 
Wibhisono, I. G. L. A. K. (2020).

Framing analysis of the kompas

COVID-19 coverage: january

2020 Edition. Jurnal ASPIKOM,

5(2), 219-231. Retrieved from

https://doi.org/10.24329/aspikom.

v5i2.717

Yuniar, R. W. (2020). Haji : Polemik

ibadah haji batal tahun ini, dari

hoaks dana haji sampai Aceh ingin

berangkatkan jemaah haji sendiri.

$B B C$ News. Retrieved from

https://www.bbc.com/indonesia/m

ajalah-53096726\%0A\%0A 
This page intentionally left blank. 